\title{
Development of knowledge in the pre-industrial era - a historical perspective
}

\author{
Wojciech Bizon ${ }^{1, *}$, and Natalia Lubińska ${ }^{2}$ \\ ${ }^{1}$ University of Gdańsk, Faculty of Economics, Macroeconomics Department, 119/121 Armii \\ Krajowej St., 81-824 Sopot, Poland \\ ${ }^{2}$ University of Gdańsk, Confucius Institute, 80-952 Gdańsk, Bażyńskiego 1a, Poland
}

\begin{abstract}
Knowledge is the source of a progress in a modern economy. This progress, however, was not sustainable or even as rapid in the past as it is today. The article explains the evolution of knowledge over the ages: how it was manifested and what its influence was on the economy and on society in the pre-industrial era - up until the industrial revolution and the dissemination of capitalism.
\end{abstract}

The very concept of knowledge has never been explicit. It is certain, however, that in no period of human history did knowledge pay the same role. Its value was perceived differently, and the focus on its collection varied as well. Despite the recognition by contemporary researchers that the most important factor used to preserve and disseminate knowledge was the development of writing [1], the problem of identifying the sources of knowledge advancement is much broader and encompasses not only the questions of writing but the very fact of the capacity to copy knowledge as well (developing a shared spoken language) and the discovery of numerous applications that stem from the laws of mechanics. Jürgen Renn adds to the triad of language-writing-mechanics the Neolithic progress in agriculture, which is identified with the food production revolution [2], creating a coherent concept of evolution and the role of knowledge: from the development of the spoken language and enabling the transfer of knowledge, through acquiring the skill of its archiving in a written form on the one hand, to the use of its resources for the social and economic advancement and the subsequent technological progress on the other hand. This expression allows the integration of various conceptual systems that refer to knowledge into a coherent (albeit incomplete) concept, which treats knowledge as an encoded form of experience. At present, in the time of collecting vast quantities of knowledge and science development, an important chain in the process of knowledge circulation is played by education, which involves institutionalised learning. The following model contributes to the applicability of this knowledge in practical actions: scientific research - knowledge - education - action - (other) new knowledge [3]. In this concept, scientific research creates and enriches the stock of knowledge. And knowledge, in turn, is transferred via a formal learning to the society (education).

* Corresponding author: w.bizon@ug.edu.pl 


\section{Egypt}

Although knowledge was the source of progress, it did not determine it completely. For example, Egyptians possessed profound knowledge within mechanics, medicine, and astronomy. Designing and erecting monumental pyramids proves their advanced knowledge of architecture. To this day, researchers have only partially explained the technical issues related to the complicated stone processing and transport of mega-tone blocks to a construction site [4]. Furthermore, preserved surgical tools found during archaeological studies show the popularity of operations on eyes and brain as well as the production of dentures. Calculating the length of an astronomic year and developing a solar calendar indicates also the progress of astronomical science in the delta and valley of the Lower Nile. Numerous historians, however, stress the empiric character of knowledge held by Egyptians, resulting from experience applied indiscriminately. This conclusion stems from the fact that in the ancient Egypt, despite the collection of various types of knowledge, progress in areas such as the organization of economy and social life was exceptionally limited during the period of three thousand years [5]. That state of affairs was certainly fostered by the focus of knowledge among the clearly distinguished and hermetic group of people, who were separated from the rest of the society.

\section{China}

In ancient China the aspect of knowledge and its acquisition looked slightly different. In the Middle Kingdom knowledge and skills confirmed with formal education as well as moral excellency predestined one to occupy important positions more than one's birth. According to Confucian ideals, knowledge gave the opportunities of social advancement to persons, thus contributing to major changes in the social structure in the ancient China.

The development of the Chinese civilization involved inventions (e.g. gunpowder, paper production, a compass, print, and advanced sowing techniques) [6]. Already in the ancient times, the Chinese fostered the development of astronomy and mathematics. One of the key achievements was the development of the first seismograph by a Chinese scientist, Zhang Heng, in $132 \mathrm{AD}$. He was also an inventor of the spherical astrolabe fed with water, used to measure the location of celestial bodies [7]. Numerous historians recognise as the most fertile period in science to be the Han epoch (206 BC - 220 AD). The development of Chinese technique in that period not only matched but in many aspects outpaced other centres of the global civilization. There is no doubt that the system of knowledge classification and its sources in the Middle Kingdom should be especially appreciated [8]. Studies of the history and culture of state as well as the collection of classical works of Chinese literature contributed to the development of historic writing.

However, the growth of Confucian orthodoxy and the model of Chinese state gradually created the system that tended to promote characteristics other than inventiveness among the most talented members of the society, leading to the disappearance of the innovative advantages of China finally in the meanders of the bureaucratic feudalism in C14. The main reasons lied in the attachment to tradition and the system of education that formed future elites. They were subject to the regime of formal examinations, to continue the career in the administration at the imperial court, which was considered to be a most attractive path in those times. Hence, the class of enlightened bureaucrats was established, who were appreciated mostly for their capacity to learn by heart and mechanically whole verses of Confucius writings and for their faithfulness to tradition. As a result, the knowledge of mathematics, exact sciences, and the ability to experiment suffered [9]. 


\section{Greece}

In the western world the noticeable explosion of knowledge occurred in C6 BC. It started in Greece and developed owing to the major progress in mathematics, to achieve its peak in the revolutionary theories of matter and force [5]. It was there, in the ancient Greece, where culture gradually broke up with the magical and mythical concept of a human being and its place in the nature and at the same time presented the perspective towards the philosophical and scientific approach. (...) At the same time, an absolutely new type of knowledge was born - deductive reasoning, which derived theorems from axioms [10]. A breakthrough facilitation became the invention of alphabet (owing to contacts between Phoenicians and Greeks), as a coherent system that enabled the reliable and precise recording of knowledge from various fields. C5 BC saw the birth of a systematic approach to the study of knowledge about the past, i.e. the explanatory description of time of human generations that was historical as contrary to mythical. History and ethnography contributed to the development of descriptive geography, while the further development of mathematics and astronomy enabled the creation of mathematical geography and revolutionised cartography [11]. After $525 \mathrm{BC}$, the Pythagoreans advanced a thesis that the Earth was a globe, and already in C4 $\mathrm{BC}$ Aristoteles proved scientifically the roundness of the Earth and determined that the globe had to be divided into zones [12]. In the field of mathematics, there were the first attempts at using methods of mathematical analysis (in its modern understanding) [13]. What is more, when designing tools and sites of work the laws of ergonomics were taken into account [14]. However, the subject of never ending discussions among researchers is the question why all the more advanced inventions of Greeks remained technical curiosities, instead of revolutionising the life of societies, as happened from C15 of our era [15].

\section{Rome}

In the ancient republican Rome science was practised exclusively for practical purposes. According to the basic attitude of the society, science was subordinated to the needs of the city. Mathematics was an auxiliary science of architecture, astronomy affected the development of a calendar, while geography had a descriptive character. The work that affected the posterity greatly was the encyclopaedia Disciplinarum libri IX (Nine Books of Discipline) by Marcus Terentius Varro. It was read until the end of antiquity, and was used by the most prominent scholars, starting from Pliny the Elder to Isidore of Seville [11]. In the late antiquity and the Middle Ages, it became the foundation of education based on the two-level division of teaching and all sciences into trivium (grammar, dialectics, and rhetoric) and quadrivium (geometry, arithmetic, astronomy, and music) [16]. In the area of technical knowledge, Romans possessed broad knowledge of architecture and construction as well as hydraulics. Its application in the process of laying roads was a significant innovation of that period [17].

During the Roman Empire period (since C1 BC), knowledge was also classified in a certain manner. At the boundary between antiquarian practice and the knowledge of nature there is the only preserved antic encyclopaedia, Naturalis historia (Natural History) by Pliny the Elder [18]. The work was composed of 37 books, organised in ten volumes, which covered the issues of anthropology, physiology of man, agriculture, and mineralogy. It was dedicated to Emperor Titus in 77 (or 78) AD and was a model for the next fifteen hundred years. It was copied in large numbers; therefore, the manuscripts (in whole or in part) circulated in the Western Europe throughout the Late Antiquity and the Middle Ages [11]. After the downfall of the Roman Empire, there was the period of the advancement of the Muslim world, for which the Arabic language became the means of communication and the medium of culture. That phenomenon was emphasized by the establishment of Coran legal 
interpretation schools, where comparative work was carried out on hadiths [stories that present words or deeds of Prophet Mahomet]. Bagdad was an unrivalled intellectual centre between $\mathrm{C} 8$ and $\mathrm{C} 11$, to which contributions were made from various parts of the world into the development of the works of literature, philosophy, medicine, science of astronomy, and mathematics. Another scientific field was opened up before the Muslims, namely geography, born out of the discoveries of the world by Arab conquerors and merchants [19].

\section{Near East}

As a result of the Muslim conquest (C7 and C8), knowledge from the countries of the Northern Africa and Asia Minor reached the Mediaeval Europe as well. The most important achievements included the use of Arabic digits, which enabled the further progress in arithmetic. Beforehand, a major hindrance in the development of mathematical sciences was the obsolete system of Roman digits and the use of abaca [20]. The Arabic contribution into the development of medicine has to be kept in mind, in particular surgery. A prominent figure in this area was Abulcasis (Abu al-Qasim al-Zahrawi), the author of a handbook that included an extensive discussion of issues of operational medicine, descriptions of surgical tools, and numerous figures. For centuries, his book was a fundamental work in the early schools of medicine, even in Europe [20].

\section{India}

Indian scientists played a major role in the world of mathematics as well. Contrary to Greeks, they were involved more in arithmetic and algebra than geometry. The most prominent figures included Aryabhata (born in 476 AD), Brahmagupta (born in 598 AD), and Bhaskara (born in 1114), who developed the system of figures, where the value of every digit depended on its position; they knew how to use zero, could calculate a cube and square root, they knew fractions, the issues of percentage, permutations and combinations as well as simple arithmetic and algebraic processes. Moreover, they developed a trigonometric technique of expressing movements of celestial bodies and introduced trigonometric sine tables [21]. Interestingly, the system of education and the transfer of knowledge in the medieval India was founded on Greek and Arabic solutions, which means that in many areas it was not highly systematised and was based on individual actions, rather than on specialised institutions [22].

\section{The Middle Ages}

It is often noted that science develops best when theoretic considerations of a philosopher and a mathematician are in close contact with practical skills of a craftsman. It is also claimed that the lack of this connection in the Greek-Roman world and in the Medieval Christian world was the cause of the slow development of science, those societies are accused of. However, the skilful use of achievements in practical knowledge, through its implanting in other fields of human activity, enabled the improvement of working conditions and daily life. The apparent results of the medieval mechanical technique can be seen in construction; numerous inventions used by medieval masons to solve static problems resulting from the construction of huge churches were entirely original ideas. In the field of metallurgy of that time, the processing of iron was perfected, followed by the use of explosive and propulsive properties of gunpowder [21].

At the same time, the Middle Ages saw the development of universities (C11-C15), which evolved from bishopric schools, called stadia, and former private school institutions that taught professionals [23]. Apart from theological sciences, literature, and medicine, the 
theory of music was taught at universities, which was studied as a part of quadrivium (geometry, arithmetic, astronomy, and music) [21]. Astronomy developed as well. The oldest universities of that type were established in Paris (specialising in liberated arts and theology), Bologna (law), and Salerno (medicine) [23].

It is evident that in the medieval Europe (in particular in the early period of the Middle Ages), the focus was on storing facts collected in ancient times, rather than on attempts at their own interpretation. Only at the beginning of $\mathrm{C} 13$, based on the explanations of the Bible with rational reasons, out of the combination of empirics of technique and the rationalism of philosophy and mathematics, was the newly empiric science born, trying to discover the rational structure of the nature. Gradually, the understanding developed that the new science was not contradictory to the concept of Divine Providence, even though it led to different opinions on the mutual relationship between reason and faith [21].

A revolutionary factor in the process of collecting knowledge was the invention of print. Even though the societies at the end of $\mathrm{C} 15$ were mostly illiterate, it remains indisputable that the new medium was an excellent tool of propaganda and dissemination. The use of national languages instead of Latin and the application of illustrations gained new readers, not connected with intellectual circles [23]. A thesis can be ventured that the simplification of the editing work and the related mass print of publications as well as the discovery of new lands, which resulted in the departure from the predominant image of the shape of the contemporary world, constituted another turning point, also for the development of knowledge and science.

\section{The Renaissance and 17th century}

After the medieval slowdown, only did the Renaissance rediscover knowledge and education as characteristics necessary for a 'critical' man. A 'critical' man could move freely in all areas of life, could boil down rich detailed knowledge to its general form and vice versa. During the Renaissance, the special emphasis was on comprehensive education, including the teaching of so-called seven arts: grammar, rhetoric, logic, arithmetic, geometry, astronomy, and music. Renaissance also created a new concept of man. Great contribution into the humanistic philosophy of man in $\mathrm{C} 15$ and $\mathrm{C} 16$ came from humanists, the admirers and artists of the Renaissance. The discovery of a 'reasonable person' and putting it on a pedestal was the core of the culture during the Renaissance [23].

Renaissance and $\mathrm{C} 17$ were the period of geographic discoveries and expansion (the further discovery of the America, finding the way to the East India, the conquest of Mexico, travels round the Earth, circumnavigating Australia), which were accompanied by the development of astronomy and astronomic practice (Copernicus, Brahe ${ }^{1}$, Galileo ${ }^{2}$, Lippershey $^{3}$, and Kepler ${ }^{4}$ ) and cartography $\left(\right.$ Behaim $^{5}$ and Merkator ${ }^{6}$ ). The new epoch

\footnotetext{
1 Tycho Brahe (1546-1601) - A Danish astronomer and writer known for his accurate and comprehensive astronomical and planetary observations. He was assisted by Johannes Kepler, who later used Tycho's astronomical data to develop his three laws of planetary motion.

${ }^{2}$ Galileo (Galileo Galilei) (1564-1642) - was an Italian polymath. Galileo is a central figure in the transition from natural philosophy to modern science and in the transformation of the scientific Renaissance into a scientific revolution [24].

${ }^{3}$ Hans Lippershey (1570-1619) - in 1608 build a telescope.

${ }^{4}$ Johannes Kepler (1571-1630) - was a German mathematician, astronomer, and astrologer. He is best known for his laws of planetary motion [25].

${ }^{5}$ Martin Behaim (1459-1507) - He is now best known for his "Erdapfel", the world's oldest surviving globe, which he produced for the Imperial City of Nuremberg between 1491-1493.

${ }^{6}$ Gerard Merkator (Gerardus Mercator) (1512-1594) -a German-Flemish cartographer, geographer and cosmographer. He was renowned for creating the 1569 world map based on a new projection which
} 
initiated the great colonial expansion of Europeans, mostly the Portuguese and Spanish, followed by the Dutch, English, and French. The new changes influenced the economic life of Europe. The former commercial powers (Italian and Hanseatic cities) lost most of their importance, while oceanic states began to dominate [26].

The interest in ancient literature and science did not disappear completely in the Middle Ages, or especially during the Renaissance. As a result of importance attributed to mathematics in the Renaissance (C16), the works by Archimedes were translated and published, resulting in the strong intellectual ferment against the predominant position of works by Aristotle and scholastics. The intellectual climate of the Renaissance aroused the great interest in the thought of Ancient Greece. As a result, the European mathematics began to develop based on two influences: Arabic arithmetic and algebra and Greek geometry. At the end of $\mathrm{C} 15$, del Ferro ${ }^{7}$ found a general solution of a cubic equation, and Ferrari ${ }^{8}$ discovered a method of solving a quartic equation in 1540 . In C17, analytical geometry was founded by Descartes ${ }^{9}$ and Fermat ${ }^{10}$, a calculus was created by Newton ${ }^{11}$ and Leibniz ${ }^{12}$ and the theory of probability was formulated (Pascal ${ }^{13}$ and Fermat) [27].

The subsequent diffusion of knowledge was supported by the dissemination of inventions, especially, as mentioned above, the development of print, which significantly improved the accessibility of knowledge and made further education easier. At the same time, the broader application of experiments and mathematics resulted in the development of detailed sciences. At the beginning of $\mathrm{C} 17$, the systematic use of new methods based on experiments and mathematic abstraction gave such outstanding results that it was given the name of 'scientific revolution' [21]. As a consequence, the method of conceptualizing reality changed; quantifying methods began to be used to describe studied dependencies and the measurement of their changes [28].

The Renaissance's interest in the truths of objective world paved the way for the subsequent concrete inventions and discoveries. A textbook example that illustrates such phenomena are the effects of publishing the work of Isaac Newton in 1687 entitled Philosophiae naturalis principia mathematica (Mathematical Principles of Natural Philosophy). Its deistic and mechanistic outlook on the world, starting from the critics of the Cartesian physics, created the science of classical mechanics with its most outstanding achievements - the law of gravity [26]. However, progress was made only when inventors succeeded in implementing the ideas of Newton concerning the foundations of movement and dynamics in practical technical achievements, which contributed to the unprecedented growth of economic effectiveness. Hence, the list of inventions from $\mathrm{C} 17$ includes a telescope, a microscope, an air pump for producing vacuum, a pendulum clock, an apparatus for generating electricity, and a thermometer.

\footnotetext{
represented sailing courses of constant bearing (rhumb lines) as straight lines - an innovation that is still employed in nautical charts.

${ }^{7}$ Scipione del Ferro (1465-1526) - an Italian mathematician (Bologna).

${ }^{8}$ Lodovico Ferrari (1522-1565) - an Italian mathematician (Bologna).

${ }^{9}$ René Descartes (1596-1650) - was a French philosopher, mathematician, and scientist.

${ }^{10}$ Pierre de Fermat (1601-1665) - was a French lawyer and a mathematician.

${ }^{11}$ Sir Isaac Newton (1642 -1726/27?) - was an English mathematician, astronomer, theologian, author and physicist.

${ }^{12}$ Gottfried Wilhelm Leibniz (1646-1716) - was a prominent German polymath and philosopher in the history of mathematics and the history of philosophy.

${ }^{13}$ Blaise Pascal (1623-1662) - was a French mathematician, physicist, inventor, writer and Catholic theologian.
} 


\section{18th century}

Also $\mathrm{C} 18$ brought numerous inventions and discoveries in varied branches of science (botany, history of arts, and technique). Due to the dynamism of that century, it is often described as a 'revolution' in different categories: industry, finance, agriculture, and demography. Numerous historians, especially British ones, are sceptical about naming this process in this manner. This was not a rapid development of technical and industrial civilization, but C18 can be described as the initial stadium of accelerated development [29]. The development of modern science liberated individual disciplines from scholastic philosophy. However, general natural sciences remained under its influence (physics considered to be philosophia naturalis). Despite the great discoveries of Copernicus, Kepler, and Galileo, no strict methods for the science of nature had been discovered yet.

An important aspect of developing the modern science would be its exit from the narrow circle of insiders, by drawing conclusions from the discoveries of predecessors, the coordination of research, the dissemination and popularization of findings, and the mass production of scientific apparatus [29]. It is worth noting several events that were most important for the world of knowledge in C18. In 1758, the 10th edition of Systema naturae by Linnaeus was published, which presented a hierarchic scheme of classifying three kingdoms of nature and the binominal terminology. It became adopted in science, ordering the available information and making further research easier. In 1776, Adam Smith announced his work An Inquiry into the Nature and Causes of the Wealth of Nations, which became a starting point for the development of modern economics. The aeronautics began (Montgolfier brothers ${ }^{14}$ ) with a fly in a balloon. The theory of electricity was developing $\left(\right.$ Galvani ${ }^{15}$ ), and the industry was modernised (the invention of a loom weaving machine by Arkwright ${ }^{16}$ ). One cannot leave out the great contribution of Leonhard Euler. We owe him his work on a differential calculus and integral calculus, the graph theory and the development of mathematical terminology and notation. In chemical research a breakthrough was made by Lavoisier, who determined the chemical composition of water and air and examined the process of combustion.

The last decades of C18 brought an unprecedented number of technical inventions. That phenomena resulted from the growing availability of books and magazines as well as the greater liberty of travels. Not only privileged elites had access to education and knowledge, but also the bourgeoisie and clergy. The media of those time distributed broadly cultural content and scientific knowledge all over Europe. The coming scientific and technical breakthrough was evident in the number of scientific tests, although not always successful. One such failed experiment included the invention of the first steam car in 1771 (Nicolas Cugnot), a design of a steam locomotive by an American, Olivier Evans, in 1786, and the construction of an electric telegraph.

\section{Summary}

For centuries, science was a basic element of the process of civilization. By gaining pace at the turn of $\mathrm{C} 18$ and C19, it opened a new industrial era related to the development of capitalism and free market economy, which gave the rise to globalization. Its general availability and the level of understanding processes that occur in numerous disciplines of

\footnotetext{
${ }^{14}$ Joseph-Michel Montgolfier (1740-1810), Jacques-Étienne Montgolfier (1745-1799).

${ }^{15}$ Luigi Galvani (1737-1798) - was an Italian physician, physicist, biologist and philosopher, who discovered animal electricity.

${ }^{16}$ Sir Richard Arkwright (1732-1792) - was an English inventor and a leading entrepreneur during the early Industrial Revolution.
} 
science, differentiated the role of knowledge during ages. In the ancient and medieval times, it did not go beyond the fulfilment of practical needs and collecting facts, without their further development. A scientific activity was also limited to the elitist circle of rulers, priests, and clerks. Another hindrance to the development of knowledge was common illiteracy and no interest in the education of larger masses. With the approach of the Renaissance, science started to impact the society more. The process of establishing universities and the subsequent popularization of print became a catalyst of the early 'scientific revolution'. The boom of scientific experiments and technical innovation in $\mathrm{C} 17$ and $\mathrm{C} 18$ only confirmed that thesis. This study shows the gradual process of departing from the noncritical application of empiric knowledge based on experience and the move towards conscious reasoning. It also proves that knowledge was certainly a source of progress, although it did not determine it completely. The evolution of the role of knowledge shows also the need to treat it as a coded form of experience, by which the society can anticipate the consequences of advances of civilization.

\section{References}

1. J. Goody, Literacy and the Diffusion of Knowledge cross Cultures and Times, [in:] G. Barna Navaretti, P. Dasgupta, K.-G. Mäler, D. Siniscalco [ed.], Creation and Transfer of Knowledge. Institutions and Incentives, (Springer, Heidelberg, 2010)

2. J. Renn, Centaurus, 57, 37-53 (2005)

3. W. Bizon, Wiedza i jej transfer - szkic teoretyczny, [in:] A. Grzybowski [ed.], Transfer wiedzy w ekonomii i zarzadzaniu, (Wydawnictwo Uczelniane Akademii Morskiej w Gdyni, Gdynia, 2011)

4. J. Wolski, Historia Powszechna Starożytność, (Państwowe Wydawnictwo Naukowe, Warszawa, 1965)

5. Ch. van Doren, Historia wiedzy. Od zarania dziejów do dziś, (Wydawnictwo al fine, Warszawa, 1997)

6. A. Borowiecki, Polityka. Pomocnik Historyczny, 9, 74-79 (2012)

7. W. Rodziński, Historia Chin, (Zakład Narodowy imienia Ossolińskich, Wrocław, 1974)

8. S. Jiang, Libraries \& the Cultural Record, 42, 1-20 (2007)

9. W. Hübner, Kwartalnik Naukowy Uczelni Vistula, 2 (36), 16-39 (2013)

10. V. Hosle, Philosophie der okologischen Krise: Moskauer Vortrage, (Verlag, C.V.Beck, Munchen, 1991), as cited in: Z. Łepko, Seminaria. Poszukiwania naukowe, 27, 77-86 (2010)

11. A. Ziółkowski, Historia Powszechna. Starożytność, (Wydawnictwo Naukowe PWN, Warszawa, 2009)

12. Historia powszechna. Starożytny Egipt, Grecja i świat helleński Biblioteka „Gazety Wyborczej" tom 3, (Warszawa, UTET Cultura, 2007)

13. K. Černeková, WDS'08 Proceedings of Contributed Papers Part I, (Matfyzpress, Prague, 2008)

14. N. Marmaras, G. Poulakakis, V. Papakostopoulos, Applied Ergonomics, 30, 361-368 (1999)

15. H. Dahlmann, RE Suppl. VI, (1935), as cited in K. Tadajczyk, Status społeczno-prawny i odpowiedzialność lekarza w prawie rzymskim, (Łódź, Uniwersytet Łódzki, 2014) 
16. W. Kopaliński, Słownik mitów i tradycji kultury, (Państwowy Instytut Wydawniczy, Warszawa, 1987)

17. Historia powszechna. Epoka Augusta i cesarstwo rzymskie Biblioteka „Gazety Wyborczej" tom 5, (Warszawa, UTET Cultura, 2007)

18. J. Loveland, S. Schmitt, Annals of Science, 72, № 1, 2-27 (2015)

19. Historia powszechna. Od upadku cesarstwa rzymskiego do ekspansji islamu. Karol Wielki Biblioteka Gazety Wyborczej tom 7, (Warszawa, UTET Cultura, 2007)

20. P.K. Hitti, Dzieje Arabów, (Państwowe Wydawnictwo Naukowe, Warszawa, 1969)

21. A.C. Crombie, Nauka średniowiecza i początki nauki nowożytnej tom 1, (Instytut Wydawniczy PAX, Warszawa, 1960)

22. S.Z. Husain Jafri, Intellectual Discourse, 20:1, 79-102 (2012)

23. T. Manteuffel, Historia Powszechna Średniowiecze, (Państwowe Wydawnictwo Naukowe, Warszawa 1968)

24. A. Benedikt, Perspectiva. Legnickie Studia Teologiczno-Historyczne, 2, 202-220 (2004)

25. J.E. Greivenkamp, D.L. Steed, [in:] R.J. Koshel, G.G. Gregory [ed.], Novel Optical Systems Design and Optimization XIV Proceedings of SPIE, 8129, 1-18 (2011)

26. Z. Wójcik, Historia Powszechna XVI-XVII wieku, (Państwowe Wydawnictwo Naukowe, Warszawa, 1973)

27. R.P. Kostecki, liber naturae rerum, http://www.fuw.edu.pl/ kostecki/histmat.pdf (retrieved 18.07. 2018)

28. E.C. Harwood, The American Journal of Economics and Sociology, 13, № 2 January, 113-128 (1954)

29. E. Rostkowski, Historia powszechna Wiek XVIII, (Państwowe Wydawnictwo Naukowe, Warszawa 1977) 